\title{
DETECTION OF BLOODSTAINS ON COTTON FABRIC AFTER WASHING
}

\author{
Ivan Stojanović
}

\begin{abstract}
After a criminal act a perpetrator may try to wash the bloodstains, either by hand wash in cold water or using a regular washing machine. The washing procedure can alter original bloodstains on fabric. The current experiment was focused on determining an effect of blood drying time and various washing conditions (water temperature, detergent use, machine, and hand wash simulated washing) on presentation of bloodstains on washed cotton fabric. The result of this experiment suggests that regular hand wash procedure in cold water $\left(30^{\circ} \mathrm{C}\right)$, regardless of drying time lapsed from the deposition of blood on fabric until washing, would not be sufficient to completely remove or destroy original contour of the bloodstain on cotton fabric. All tested samples washed at 60 and $95^{\circ} \mathrm{C}$ suggest that a machine washing procedure with the usage of detergent should be sufficient for removing visible bloodstains from cotton fabric, but not for latent bloodstains. As an advice for prosecutors, even in case of no obvious bloodstains, bloodstain pattern analysts should always examine clothing of the suspects in all criminal cases connected with bloodshed event.
\end{abstract}

Acta Medica Medianae 2019;58(1):24-27.

Key words: bloodstain, analysis, presumptive blood test

The Institute of Forensic Medicine, Niš, Serbia

Contact: Ivan Stojanović

Dr Zorana Djindjića Boulevard 81, 18000 Niš, Serbia

E-mail: stojanovic81@gmail.com

\section{Introduction}

Criminal act connected with external hemorrhage of a victim usually leads to a deposition of bloodstains on a perpetrator's clothing. A perpetrator may try to wash the bloodstains, either by hand wash in cold water or using a regular washing machine. Washing procedure can alter original bloodstain on fabric, so bloodstain can become diluted or hard to see with the naked eye (1-6).

Washing experiments with bloodstained fabrics revealed that detergent brand Ariel Washing Powder (Procter \& Gamble) removed bloodstains from washed fabrics most effectively compared with other tested detergents $(3,7)$. Based on literature data, our research was focused on two extremes: hand wash in cold water and machine wash with Ariel Washing Powder as one of the best household bloodstain removing detergent, also used for other real - life situations. Bloodstain pattern analysis on different fabrics must be held out based on a deeper charac- terization of the textile structure, even down to the yarn level $(8,9)$.

Deoxyribonucleic acid (DNA) analysis is a very expensive forensic technique, so it is important to confirm the presence of the right stain prior to sending it for DNA analysis. Presumptive tests of blood are performed to identify blood in the stain (1-3, 10). Luminol and Leuco-crystal Violet (LCV) were commonly used chemicals to develop latent bloodstains on evidence and at crime scenes (11). Experiments revealed luminol chemical interference with bleach, but this effect dissipates after 8 hours (12). In recent years, Hemastix and Bluestar forensic tablets have been considered to be very useful, reliable and low - cost presumptive blood tests $(11,13)$. These two tests were used in this experiment for detection and visualization of latent bloodstains on washed fabrics.

\section{Material and methods}

Fabric: The white $100 \%$ cotton fabric (140 $\mathrm{g} / \mathrm{m}^{2}$ ) cut out into 100 square pieces $5 \times 5 \mathrm{~cm}$ in diameter. The rest of the fabric of $3 \mathrm{~kg}$ was used to simulate a real situation washing procedure.

Stains: Blood was collected from the corpse of an autopsy conducted at the Institute of Forensic Medicine in Nis (case data: S-23/18; previously normal blood test results). Exactly $100 \mu$ of blood was deposited onto every piece of fabric and 100 samples were obtained. Every sample was made in five replicates. 
Washing machine: model Samsung, type WF80F5EOW2W/AD.

Washing: Three washing temperatures were used $\left(30^{\circ} \mathrm{C}, 60^{\circ} \mathrm{C}\right.$ and $\left.95^{\circ} \mathrm{C}\right)$ under two main conditions: washing with water or using a standard detergent (Ariel Washing Powder, Procter \& Gamble: composed of $5-15 \%$ active ionic and $<5 \%$ non-ionic surfactant-detergent, phosphates, water softener (zeolites and polycarboxylates), enzymes, optical brighteners and perfumes).

Groups of samples: Samples were ordered into four groups: M95 (machine wash at $95^{\circ} \mathrm{C}$ with detergent Ariel; 2 hours 35 minutes washing time; centrifuge: 1200 cycles/minute), M60 (machine wash at $60^{\circ} \mathrm{C}$ with detergent Ariel; 2 hours 35 minutes washing time; centrifuge: 1200 cycles/minute), A (machine simulated hand wash at $30^{\circ} \mathrm{C}$ with detergent Ariel; 35 minutes washing time; 200 cycles/ minute simulate drying out fabric by hands) and $\mathrm{R}$ (machine simulated hand wash at $30^{\circ} \mathrm{C}$ without detergent Ariel; 35 minutes washing time; 200 cycles/minute simulate drying out fabric by hands). Within every group, all samples were divided into 5 subgroups: $6 \mathrm{~h}$ ( 6 hours from deposition of blood until washing procedure), $24 \mathrm{~h}$ (24 hours from deposition of blood until washing procedure), $72 \mathrm{~h}$ (72 hours from deposition of blood until washing procedure), 10d (10 days from deposition of blood until washing procedure) and $30 \mathrm{~d}$ (30 days from deposition of blood until washing procedure).

Sample storage: Samples were stored in a dark place, without direct sunlight, at $20^{\circ} \mathrm{C}$, relative humidity at about 35\%, almost without air flow.

Examination: After washing procedure, all samples were left to dry at room temperature and exa- mined on the next day. Examinations of samples were performed in the Biological traces laboratory of the Institute of Forensic Medicine in Nis. First, samples were examined visually under high - intensity white light. Subsequently, samples were treated with Bluestar forensic tablets solution and with Hemastix test strips.

\section{Results}

In all positive controls, blood was detected with Hemastix test strips and Bluestar forensic tablets. None of the negative controls gave positive results after washing in water or with the detergent.

A single simulated hand wash procedure in cold water $\left(30^{\circ} \mathrm{C}\right)$ was not sufficient to remove the bloodstain from cotton fabric or completely destroy original contour of the bloodstain, regardless of drying time lapsed from the deposition of blood on fabric until washing. All of these samples had bloodstains on washed fabric with a partially faded contour of original stain. Some visible blood transfer from original bloodstain was noted onto fabric. The most of transfer staining was noted on the part of the fabric that was in close contact with the fabric containing original bloodstain, at the moment of extracting the fabric from the washing machine.

A machine washing procedure in hot water $\left(60\right.$ and $95^{\circ} \mathrm{C}$ ) with Ariel detergent was sufficient to remove visible bloodstains from cotton fabric, but all samples gave positive results on presumptive blood tests. There was no visible blood transfer on previously clean parts of the fabric, but Bluestar forensic tablets solution gave a diffuse positive result on the wide area of tested cotton fabric.

Table 1. Bloodstain examination test results on cotton fabric after washing

\begin{tabular}{l||c|c|c|c|c||}
\hline \hline \multirow{2}{*}{$\begin{array}{c}\text { Washing } \\
\text { procedure }\end{array}$} & \multicolumn{5}{|c|}{ Time lapsed from deposition of blood on cotton fabric until washing } \\
\cline { 2 - 6 } & 6 hours & 24 hours & 72 hours & 10 days & 30 days \\
\hline M95 & 0 & 0 & 0 & 0 & 0 \\
\hline M60 & 0 & 0 & 0 & 1 & 1 \\
\hline A & 1 & 1 & 1 & 1 & 1 \\
\hline R & 1 & 1 & & \\
$1-$ visible bloodstain and positive presumptive tests; \\
M95 - machine wash at $95^{\circ} \mathrm{C}$ with detergent Ariel; \\
M60 - machine wash at $60^{\circ} \mathrm{C}$ with detergent Ariel; \\
A - machine simulated hand wash at $30^{\circ} \mathrm{C}$ with detergent Ariel; \\
R - machine simulated hand wash at $30^{\circ} \mathrm{C}$ without detergent Ariel.
\end{tabular}

\section{Discussion}

A washed cotton fabric with bloodstains presents several challenges for the bloodstain pattern analyst. First and the most important, the visible bloodstains and staining fabric with Bluestar reagent bore a little overall resemblance to the initial blood staining. Initial bloodstain patterns could be seen in most of the samples washed in cold water with or without detergent, but they were often intermingled with the "background noise" staining. Analysts must be very careful when interpreting these diffused stains. In the literature, some authors suggest that diffused bloodstains on washed fabric must not be 
interpreted as a result of any action other than washing (14). The result of this experiment suggests that regular hand wash procedure in cold water $\left(30^{\circ} \mathrm{C}\right)$, regardless of drying time lapsed from the deposition of blood on fabric until washing, would not be sufficient to completely destroy original contour of the bloodstain on cotton fabric.

In the current research, Ariel was used as the most reliable detergent for removing bloodstains from fabric $(3,7)$. All tested samples washed at 60 and $95^{\circ} \mathrm{C}$ suggest that a machine washing procedure with the usage of detergent should be sufficient for removing visible bloodstains from cotton fabric. Subsequently, Hemastix strip test and Bluestar forensic tablets reagent were applied to all of these tested samples. Clear positive result registered on all tested samples. This result suggests that s single household machine washing cycle, regardless of washing program and usage of detergent, is not sufficient for completely removing visible and latent bloodstains from cotton fabric.
According to the result of this experiment, in real criminal cases, the analysts could provide very useful information to prosecutors about bloodshed event if the data about washing procedure were reliable and well known.

\section{Conclusion}

Regardless of washing program, a single household machine washing cycle is not sufficient for removing both visible and latent bloodstains from cotton fabric. The data revealed after performing the current study encourage analysts that there is a high probability of finding bloodstains on cotton fabric after washing with detergent. As an advice for prosecutors, even in case of no obvious bloodstains, bloodstain pattern analysts should always examine clothing of the suspects in all criminal cases connected with bloodshed event. Future systematic research in this field could provide more reliable data about the effect of washing procedure on bloodstained fabrics.

\section{References}

1. Bevel T, Gardner RM. Bloodstain Pattern Analysis with an Introduction to Crime Scene Reconstruction. 3rd ed. The United States: CRC Press; 2008. [CrossRef]

2. James SH, Kish PE, Sutton TP. Principles of bloodstain pattern analysis - theory and practice. Boca Raton FL: CRC Press Taylor and Francis Group; 2005. [CrossRef]

3. Mushtaq S, Rasool N, Firiyal S. Detection of dry bloodstains on different fabrics after washing with comercially available detergents. Aust J Forensic Sci 2016; 48(1): 87-94. [CrossRef]

4. Attingera $D$, Moore $C$, Donaldson A, Jafari A, Stone HA. Fluid dynamics topics in bloodstain pattern analysis: Comparative review and research opportunities. Forensic Sci Int 2013; 231(1-3): 375-96. [CrossRef] [PubMed]

5. Gifford WD. Bloodstain Survival in Water. IABPA News 1999; 15(2): 1-6.

6. Adair TW. Casting two-dimensional bloody shoe prints from concrete, fabric, and human skin: a review of several methods with recommendations. IABPA News 2005; 12: 4-8.

7. Arjun RI, Ashish P. Identification of bloodstains on different fabrics after washing with routinely used detergents in India. Aust J Forensic Sci 2016; 1(1): 1-5.

8. Li X, Li J, Michielsen S. Effect of yarn structure on wicking and its impact on bloodstain pattern analysis
(BPA) on woven cotton fabrics. Forensic Sci Int 2017; 276: 41-50. [CrossRef] [PubMed]

9. Ramsthaler F, Schmidt P, Bux R, Potente S, Kaiser C, Kettner M. Drying properties of bloodstains on common indoor surfaces. Int J Legal Med 2012; 126: 73946. [CrossRef] [PubMed]

10. Andrews C, Coquoz R. PCR DNA typing of washed stains. Advances in Forensic Haemogenetics: Series Haemogenetics 1994; 343-5.

11. Tobe SS, Watson N, Daéid NN. Evaluation of six presumptive tests for blood, their specificity, sensitivity, and effect on high molecular-weight DNA. J Foren sic Sci 2007; 52(1): 102-9. [CrossRef] [PubMed]

12. Creamer JI, Quickenden TI, Crichton LB, Robertson P, Ruhayel RA. Attempted cleaning of bloodstains and its effect on the forensic luminol test. Luminescence 2005; 20(6): 411-3. [CrossRef] [PubMed]

13. Vennemann M, Scott G, Curran L, Bittner F, Tobe SS. Sensitivity and specificity of presumptive tests for blood, saliva and semen. Forensic Sci Med Pathol 2014; 10(1): 69-75. [CrossRef] [PubMed]

14. Adair TW, Shaw RL. Enhancement of Bloodstains on Washed Clothing Using Luminol and LCV Reagents. IABPA News 2005; 4-10. 


\title{
DETEKCIJA KRVNIH MRLJA NA PAMUČNOJ TKANINI NAKON PRANJA
}

\author{
Ivan Stojanović
}

Zavod za sudsku medicinu u Nišu, Srbija

Kontakt: Ivan Stojanović

Bulevar dr Zorana Đinđića 81, 18000 Niš, Srbija

E-mail: stojanovic81@gmail.com

Nakon krivičnog dela izvršilac može pokušati da opere tragove krvnih mrlja ili ručnim pranjem ili pranjem u veš mašini. Proces pranja može izmeniti prvobitni izgled krvnih mrlja na tkanini. Aktuelno istraživanje je bilo usredsređeno na utvrđivanje efekta protoka vremena od nanošenja krvne mrlje do pranja i efekta različitih modaliteta pranja (temperatura vode, upotreba deterdženta, mašinsko pranje i mašinski simulirano ručno pranje) na izgled krvnih mrlja na opranoj pamučnoj tkanini. Rezultat ovog eksperimenta ukazuje da obično ručno pranje u hladnoj vodi $\left(30^{\circ} \mathrm{C}\right)$, nezavisno od protoka vremena od nanošenja krvi na tkaninu do pranja, ne bi bilo dovoljno za kompletno uklanjanje ili narušenje prvobitne konture krvne mrlje na pamučnoj tkanini. Svi uzorci prani na 60 i $95^{\circ} \mathrm{C}$ ukazuju da bi mašinsko pranje sa primenom deterdženta trebalo biti dovoljno za uklanjanje vidljivih krvnih mrlja sa pamučne tkanine, ali ne i onih nevidljivih. Savet tužilaštvima je da bi, u svim slučajevima izvršenja krivičnih dela povezanih sa krvoprolićem, čak i ako nema očiglednih tragova krvi, analitičar obrazaca krvnih mrlja trebalo da uvek izvrši pregled odeće osumnjičenog.

Acta Medica Medianae 2019;58(1):24-27.

Ključne reči: krvna mrlja, analiza, prezumptivni test krvi 